\title{
KONTEKS BUDAYA GAMBAR BINATANG PADA SENI CADAS DI SULAWESI SELATAN
}

\author{
Yosua Adrian Pasaribu \\ Mahasiswa S2 Arkeologi Fakultas IImu Pengetahuan Budaya, Universitas Indonesia, y.pasaribu@yahoo.com
}

DOI: 10.17510/paradigma.v6i1.78.

\begin{abstract}
This article is based on a thesis with the same title on Archaeology Magister Program, Universitas Indonesia. This research relies on structuralist approach assuming that artists have potential choices to select motifs according to their artistic repertoire. That appropriate choices are guided by the site location in the region. Etnographic studies of animal motifs in rock art shows totemism, shamanism, and everyday life as cultural contexts. Based on that cultural contexts, it is known that shamanism was the cultural context of rock art in South Sulawesi which is dominated by one animal motif.
\end{abstract}

\section{KEYWORDS}

Rock art; animal motifs; cultural context; South Sulawesi.

\section{Pendahuluan}

Pulau Sulawesi merupakan daerah pertemuan antara fauna dari dataran Sunda (Asia) dan dari dataran Sahul (Papua-Australia) [Intan 2008,19]. Kondisi Sulawesi sebagai pulau yang membatasi aliran genetik dengan daerah di sekelilingnya dalam waktu yang sangat panjang menghasilkan fauna endemik sebagai akibat evolusi lokal karena isolasi geografis, antara lain Babyrousa babyrousa (babirusa), Bubalus depressinorcis (anoa).

Persebaran manusia di Sulawesi pada masa Holosen ( \pm 11.700 tahun yang lalu), ketika Kepulauan Indonesia sudah terbentuk seperti saat ini, hanya dapat dilakukan melalui jalur laut baik dari arah utaraselatan maupun timur-barat [Widianto 2008, 23-24]. Kecilnya jumlah sisa fisik manusia dari masa Holosen di Sulawesi yang terbatas pada pertanggalan paling tua \pm 4000 tahun yang lalu dan memiliki ciri fisik ras Mongoloid menyebabkan kekosongan aspek antropologi ragawi manusia pendukung tradisi seni cadas di Sulawesi Selatan [Widianto 2008, 25, 30]. 
Seni cadas adalah menggambar, menggores, atau memahatkan pada media batuan keras atau padas yang oleh para ahli diinterpretasikan berkaitan erat dengan religi. Seni cadas ditemukan di berbagai situs Palaeolitik di Eropa hingga di masyarakat tradisional pada masa kini yang melanjutkan tradisi itu di Amerika dan Australia. Seni cadas menggambarkan lingkungan sekitar atau lansekap [Whitley 1998]. Seni cadas terdiri atas gambar, motif, dan desain yang dituangkan di atas permukaan batuan atau cadas alami, seperti pada permukaan tebing atau batu besar, permukaan dinding atau langit-langit gua, atau di permukaan tanah [Whitley 2005, 3]. Seni cadas juga dikenal dengan istilah seni gua atau seni parietal (dinding gua), kata kunci yang membedakan antara seni cadas dan tinggalan purbakala yang lain adalah seni cadas dituangkan pada media cadas alam, untuk membedakan dengan seni yang dituangkan pada media buatan [Whitley $2005,3]$.

Seni cadas ditemukan di semua benua di dunia dan terkait dengan masyarakat pemburupengumpul makanan meskipun terdapat seni cadas di Kawasan Ennedi (Chad) yang dikembangkan oleh masyarakat pastoralis. Seni cadas di Indonesia ditemukan di Situs Gua Harimau (Sumatera Selatan), Kawasan Sangkulirang-Mangkalihat (Kalimantan Timur), Kawasan Maros-Pangkep (Sulawesi Selatan), Bone (Sulawesi Selatan), Kawasan Matarombeo (Sulawesi Tengah), Pulau Muna (Sulawesi Tenggara), Kepulauan Maluku, dan di Pulau Papua. Artikel ini membahas seni cadas di Kawasan Maros-Pangkep dan Bone di Sulawesi Selatan.

Para ahli berpendapat bahwa setidaknya terdapat dua periode dalam seni cadas di Sulawesi Selatan, yakni periode pra-Austronesia dan periode Austronesia. Periode pra-Austronesia didominasi oleh gambar tangan dan penggambaran motif binatang mamalia besar endemik Sulawesi dengan pewarna merah dalam ukuran besar dan gaya naturalis serta penggambaran garis-garis di bagian badan binatang yang memiliki pertanggalan antara 39 dan 17 ribu tahun yang lalu [Eriawati 2003; Aubert et al. 2014]. Seni cadas pada periode ini diduga kuat dikembangkan oleh masyarakat "serumpun" Aborigin Australia pada persebarannya di Kalimantan, Sulawesi, Seram, Maluku, Papua dan Australia pada kurun waktu 50.000 tahun yang lalu [Fage, Chazine, dan Setiawan 2010, 166].

Periode Austronesia didominasi oleh penggambaran motif binatang dalam ukuran kecil (termasuk binatang laut, seperti ikan, penyu; serta binatang domestik, seperti anjing, ayam, dan kuda), antropomorfis, dan gambar geometris, yang umumnya digambarkan dengan warna hitam (kemungkinan arang) [Eriawati 2003; Aubert et al. 2014]. Seni cadas itu diduga kuat dikembangkan oleh penutur bahasa Austronesia dan 
memiliki pertanggalan beberapa ribu tahun yang lalu [Simanjuntak 2008]. Penutur bahasa Austronesia adalah masyarakat pelaut yang berdiaspora dari Taiwan atau Cina Selatan ke Asia Tenggara dan Pasifik. Kebudayaan Austronesia identik dengan budaya neolitik, bercocok tanam, alat-alat batu kapak persegi yang digosok dan diupam, domestikasi flora dan fauna, pengembangan gerabah slip merah, dan lain-lain yang menyebar ke Indonesia sejak \pm 4000 tahun yang lalu dan mencapai Pasifik pada \pm 2000 tahun yang lalu [Widianto 2010, 105].

Berdasarkan penggambaran ayam jago di Leang Tagari (Pangkep) yang berkonteks dengan gambar antropomorf, diduga kuat seni cadas ini digambarkan dengan pertanggalan relatif minimal 3000 tahun yang lalu. Ayam hutan merah (Gallus gallus) merupakan hewan asli Asia Daratan (India, Tiongkok, dan Thailand) yang didomestikasi pada \pm 5000 tahun yang lalu dan tersebar ke Asia Tenggara Kepulauan dan Pasifik pada \pm 3000 tahun, yang lalu diduga kuat dilakukan oleh persebaran masyarakat penutur bahasa Austronesia [Storey et al. 2012].

Terlepas dari kekosongan informasi antropologi ragawi, kawasan gua prasejarah di Sulawesi Selatan merupakan "kanvas geografis" tempat masyarakat pemburu-pengumpul makanan [Eriawati 2003,18; Permana 2014, 285-290] mengembangkan tradisi seni cadas mereka. Menarik untuk dicatat bahwa salah satu penggambaran binatang babi di Leang Timpuseng (Maros) dalam seni cadas kawasan karst MarosPangkep memiliki pertanggalan \pm 35.400 tahun yang lalu [Aubert et al. 2014]. Gambar babi itu berkonteks dengan gambar tangan yang memiliki pertanggalan \pm 39.000 tahun yang lalu (kini gambar tangan pada seni cadas yang tertua di dunia) [Aubert et al. 2014]. Hasil pertanggalan itu mendekatkan aspek waktu gambar binatang pada seni cadas di Sulawesi Selatan dengan seni cadas arkaik Palaeolitik Atas Eropa dengan gambar singa dari Great Panel, Gua Chauvet-Pont-D’Arc (Prancis) yang memiliki pertanggalan \pm 36.000 tahun yang lalu [Walter 2015, 55].

Pertanggalan terbaru gambar babi di Leang Timpuseng (Maros) menunjukkan usia arkaik yang relatif sezaman dengan seni cadas Palaeolitik Atas Eropa. Keadaan itu disertai banyaknya gambar binatang (26\%) yang ditemukan di 23 dari 88 gua di kawasan seni cadas Maros-Pangkep [BPCB Makassar 2013] menimbulkan semangat untuk melakukan penerapan teori dan metode konteks budaya gambar binatang dalam seni cadas menurut Sauvet et al. [2009] pada seni cadas di kawasan itu.

Penggambaran berbagai binatang pada seni cadas merupakan fenomena global baik pada seni cadas dalam konteks arkeologi (tanpa catatan etnografi masyarakat pendukungnya) maupun dalam tradisi 
seni cadas masyarakat pemburu-pengumpul makanan kontemporer, bahkan masyarakat pastoralis [Sauvet et al. 2009]. Penggambaran figuratif binatang pada seni cadas diduga kuat merupakan salah satu repertoir seni cadas arkaik yang berkembang baik di Eropa Barat, Australia Utara, maupun di Sulawesi Selatan pada kurun waktu $>40.000$ tahun yang lalu [Aubert et al. 2014, 3-4].

Gambar binatang pada seni cadas di Sulawesi Selatan memiliki keragaman baik jenis binatang yang digambarkan maupun lokasi gua tempat jenis binatang itu digambarkan. Berdasarkan kenyataan itu, pertanyaan yang melatarbelakangi penelitian ini adalah bagaimana pola frekuensi dan persebaran gambar binatang pada seni cadas di Sulawesi Selatan serta bagaimana interpretasi konteks budaya berdasarkan pola itu?.

Penelitian ini dilakukan melalui pendekatan strukturalisme budaya yang memandang seni cadas sebagai fenomena adaptif untuk menyampaikan informasi di dalam dan ke luar kelompok sosial, manifestasi subsistem ideologi dan simbolis, dan dikaitkan dengan perilaku manusia dibandingkan ekspresi artistik individual [Berrocal 2011, 3]. Oleh karena itu, pada penelitian ini gambar binatang tidak dipandang sebagai karya individual, melainkan sebagai karya kelompok sosial yang memiliki konvensi budaya yang diekspresikan melalui seni cadas. Strukturalisme budaya ini secara umum memandang bahwa kebudayaan merupakan sebuah struktur layaknya sebuah sistem mekanisme yang menyebabkan manusia berperilaku [Smith 2001, 101].

Pada penelitian seni cadas sebagai fenomena budaya, pendekatan strukturalisme budaya dikembangkan oleh M. Raphaël [1945, 1986], A. Laming-Emperaire [1962], dan terutama oleh studi komprehensif dari A. Leroi-Gourhan [1965]. Max Raphaël (1889-1952) ialah seorang sejarawan seni Jerman-Amerika yang pertama kali mengkaji seni cadas Palaeolitik Atas di Kawasan Dordogne (Prancis) sebagai suatu kesatuan seni yang dikembangkan oleh satu masyarakat. la mengambil oposisi biner sebagai interpretasi struktur seni cadas itu, misalnya motif bison/kuda sebagai perlambang laki-laki/perempuan, kehidupan/kematian, sebagai nilai-nilai universal kemanusiaan. la menolak penggunaan analogi etnografi untuk menginterpretasi seni cadas Palaeolitik Atas. André Leroi-Gourhan (1911-1986) memelopori penelitian seni cadas secara sistematis arkeologis dengan pendekatan keruangan terhadap satuan ruang geografis gua. Interpretasi Leroi-Gourhan terkait dikotomi menyatakan bahwa gambar tertentu menyimbolkan laki-laki/ perempuan, dll. Leroi-Gourhan berpendapat bahwa gua dengan seni cadas adalah lokasi sakral tempat dilakukan ritual religi. Annette Laming-Emperaire (1917-1977) adalah murid Leroi-Gourhan yang memiliki 
pendekatan serupa dengan Leroi-Gourhan mengenai penelitian seni cadas palaeolitik di Eropa. Keduanya menekankan pada dokumentasi lengkap dari situs gua yang memiliki seni cadas dan data persebaran serta bentuknya. Ketiga ahli itu menolak penggunaan data etnografi untuk membantu interpretasi seni cadas dan menggunakan dikotomi strukturalisme yang membagi seni cadas ke dalam simbol-simbol yang mewakili oposisi biner.

Pada masa kontemporer, pendekatan strukturalisme budaya dalam kajian seni cadas dikembangkan oleh peneliti Eropa dan Australia, antara lain Georges Sauvet (Prancis), Robert Layton (Inggris), Tilman Lenssen-Erz (Jerman), Paul Taçon FSA(Australia) danAndré Wlodarczyk (Prancis). Mereka mengembangkan pendekatan para ahli terdahulu, terutama pandangan bahwa seni cadas adalah suatu kesatuan seni yang dikembangkan oleh satu masyarakat dan menggunakan metode sistematis arkeologis dalam penelitian seni cadas. Berbeda dengan para ahli terdahulu, kelima ahli itu menggunakan analogi etnografi pada tahap interpretasi.

Mereka terkenal dalam mengembangkan metode untuk mengakses "sistem mekanisme" yang menyebabkan manusia menggambarkan binatang dalam seni cadas Palaeolitik Atas Eropa. Metode itu menekankan statistik klasifikasi binatang yang digambarkan dan persebarannya secara keruangan di dalam kawasan seni cadas. Metode itu dapat menyediakan parameter struktural yang mengekspresikan frekuensi berbagai motif di dalam kawasan dan distribusinya antarsitus di dalam kawasan yang kemudian menyediakan bukti-bukti (lines of evidence) penting yang menunjukkan konteks budaya seni cadas dalam masyarakat skala kecil [Sauvet et al. 2009,15].

Dalam artikel ini, metode kerja para ahli kontemporer tersebut [Sauvet et al. 2009] diterapkan pada seni cadas di Sulawesi Selatan. Penelitian tentang seni cadas di Indonesia hingga saat ini belum menemukan catatan etnografi tentang masyarakat pendukungnya. Oleh karena itu, dalam artikel ini interpretasi struktur seni cadas dilakukan dengan analogi etnografi masyarakat yang masih menjalankan tradisi seni cadas di berbagai belahan dunia menurut data Sauvet et al. [2009].

Penelitian tentang tradisi seni cadas yang dipraktikkan oleh masyarakat pemburu-pengumpul makanan kontemporer menunjukkan bahwa dalam menorehkan gambar binatang terdapat lebih dari satu konteks budaya [Sauvet et al. 2009, 3]. Secara garis besar gambar binatang pada tradisi seni cadas masyarakat pemburu-pengumpul makanan kontemporer menunjukkan tiga konteks budaya, yaitu (1) totemisme, (2) shamanisme, dan (3) kehidupan sehari-hari/profan [Sauvet et al. 2009, 1]. 
Pengertian totetisme yang berasal dari kata totem (bahasa Ojibwa pada masyarakat pribumi Amerika Utara) mengacu ke penggunaan binatang atau tanaman tertentu sebagai emblem/simbol atau penjaga suatu kelompok sosial yang dirayakan dalam ritual [Sauvet 2009, 2]. Totemisme diklasifikasikan ke dalam bentuk religi animisme yang ide utamanya adalah manusia dan masyarakat hidup bersama dalam dunia fisik dan rohani dengan berbagai macam roh. Binatang, tanaman, dan manusia memiliki roh individual layaknya fenomena alam, seperti gunung, dan hutan. Dalam hal ini, binatang atau tanaman dengan kekuatan istimewa dapat dipuja atau terdapat peraturan yang rumit mengenai perlakuan terhadap binatang atau tanaman itu [Grant, Gorin, dan Flaming 2001, 146-148].

Konteks budaya totemisme yang mendasari tradisi seni cadas pada masyarakat pemburu-pengumpul makanan kontemporer terdapat di Colorado [Hartley 1992] dan Western Kimberley [Sauvet et al. 2009, 5], menjadi dasar kerangka analisis untuk menentukan konteks budaya seni cadas dalam konteks arkeologi. Penggambaran binatang pada tradisi gambar cadas di dua kawasan itu secara statistik menunjukkan bahwa: (1) jenis binatang tertentu digambarkan dalam frekuensi yang rendah atau sama dibandingkan keseluruhan jenis binatang yang digambarkan, dan (2) setiap jenis binatang tertentu digambarkan pada situs tertentu pula [Sauvet et al. 2009, 4].

Sementara itu, shamanisme berasal dari kata shaman dalam bahasa masyarakat Tungus di Siberia Tengah yang dapat diartikan sebagai seorang dukun atau individu yang melalui isolasi, pembatasan kebutuhan tubuh, bahkan penyiksaan diri, memperoleh penglihatan dari dunia roh untuk kemudian menjadi shaman dalam masyarakatnya [Sauvet et al. 2009, 2]. Shaman itu pada umumnya menggunakan metode trans yang dipicu oleh penggunaan zat halusinogen atau tarian dan rapalan yang berulang-ulang untuk mengobati pasiennya. Shamanisme digunakan untuk menyebutkan penggunaan roh sebagai penjaga dan penolong individu, yang dapat dihubungi melalui trans untuk menghasilkan penyembuhan/pengobatan atau keperluan hidup lain melalui seorang shaman. Istilah shamanisme digunakan oleh para ahli untuk menunjukkan bentuk religi masyarakat pemburu-pengumpul makanan, peternak, atau masyarakat ladang berpindah. Shaman sering kali digambarkan sebagai seorang penyihir dibandingkan pemimpin agama meskipun dapat pula seorang shaman berfungsi keduanya dalam suatu masyarakat [Grant, Gorin, dan Flaming 2001, 162-3].

Konteks budaya shamanisme yang mendasari tradisi seni cadas terdapat pada penggambaran eland (Taurotragus oryx) yang mendominasi (60\%) gambar binatang dari keseluruhan jenis binatang yang digambarkan pada seni cadas kawasan Drakensberg (Afrika Selatan) sebagai ekspresi shamanisme 
masyarakat Maluti San [Lewis-Williams 1981]. Konteks budaya shamanisme juga terdapat pada penggambaran jenis binatang domba gunung (Ovis canadensis) pada $51 \%$ gambar cadas di kawasan Coso Ranges, California Timur (Amerika Serikat) [Whitley 1994]. Catatan etnografi yang paling jelas menggambarkan hubungan simbolis antara binatang dan shaman ketika kondisi trans seorang shaman dalam penyembuhan pasien adalah catatan etnografi Bleek [1935-1936] yang menulis bahwa seorang shaman masyarakat Xam San di Afrika Selatan menggunakan "topi" tanduk eland ketika melaksanakan upacara penyembuhan. Secara arkeologis, penggambaran binatang pada gambar cadas yang berkaitan dengan shamanisme menunjukkan data statistik: (1) jenis binatang tertentu digambarkan sedikitnya dua kali lipat dibandingkan jenis binatang lain, dan (2) jenis binatang tertentu digambarkan hampir di semua situs [Sauvet et al. 2009, 3-4].

Konteks budaya kehidupan sehari-hari/profan pada tradisi gambar cadas banyak diperoleh berdasarkan catatan etnografi dari Australia. Dalam sebuah laporan yang tidak dipublikasi di daerah tepi pantai Cape York (Quensland Utara), terdapat catatan John dan Leslie Haviland yang menyatakan bahwa mereka diberi tahu oleh masyarakat Aborigin lokal bahwa mayoritas gambar cadas yang mereka lihat adalah hasil dari hunian jangka panjang di gua-gua sepanjang musim hujan sebagai salah satu kegiatan mengisi waktu di musim hujan [Layton 1995, 222]. Konteks budaya kehidupan sehari-hari/profan pada gambar binatang pada gambar cadas dapat juga berarti bahwa tidak ada jenis binatang tertentu yang memiliki hubungan khusus dengan masyarakat. Oleh karena itu, rekaman arkeologis menunjukkan statistik: (1) jenis binatang tertentu digambarkan dalam jumlah frekuensi yang rendah atau sama dibandingkan keseluruhan jenis binatang yang digambarkan, dan (2) jenis binatang tertentu digambarkan hampir di semua situs [Sauvet et al. 2009, 4]. Berikut merupakan pengelompokan tradisi seni cadas berdasarkan frekuensi dan persebaran gambar binatang dalam bentuk tabel. 


\begin{tabular}{|l|l|l|}
\cline { 2 - 3 } \multicolumn{1}{c|}{} & \multicolumn{2}{c|}{ Persebaran } \\
\hline \multicolumn{1}{c|}{ Frekuensi } & $\begin{array}{l}\text { Setiap jenis binatang tertentu } \\
\text { digambarkan pada situs-situs } \\
\text { tertentu. }\end{array}$ & $\begin{array}{l}\text { Jenis binatang tertentu } \\
\text { digambarkan hampir di semua } \\
\text { situs. }\end{array}$ \\
\hline $\begin{array}{l}\text { Jenis binatang tertentu } \\
\text { digambarkan sedikitnya dua kali } \\
\text { lipat dibandingkan jenis binatang } \\
\text { lain. }\end{array}$ & & Shamanisme (2) \\
\hline $\begin{array}{l}\text { Jenis binatang tertentu } \\
\text { digambarkan dalam jumlah } \\
\text { frekuensi yang rendah atau sama } \\
\text { dibandingkan keseluruhan jenis } \\
\text { binatang yang digambarkan. }\end{array}$ & Totemisme (1) & $\begin{array}{l}\text { Kehidupan sehari-hari/ sekuler } \\
(3)\end{array}$ \\
\hline
\end{tabular}

Tabel 1. Pengelompokan tradisi seni cadas berdasarkan frekuensi dan persebaran gambar binatang.

\section{Metodologi Penelitian}

Metodologi penelitian mencakup pengumpulan data, pengolahan data, dan penafsiran data. Pengumpulan data penelitian dilakukan di lapangan dan melalui studi kepustakaan: penelusuran gambar binatang dikaji pada kepustakaan yang berhubungan dengan kajian ini. Pengumpulan data di lapangan dilakukan untuk melengkapi gambar binatang pada seni cadas di kawasan karst Maros-Pangkep. Data dianalisis berdasarkan pola frekuensi dan persebarannya berdasarkan metode Sauvet dkk. [2009]. Pendokumentasian di lapangan menggunakan metode fotografi, deskripsi verbal dan piktorial, serta perekaman astronomis tentang data lokasional gua-gua secara. Teknik perekaman fotografi seni cadas yang telah pudar dibantu dengan perangkat lunak Dstretch. Foto digital seni cadas yang telah pudar kemudian ditampakkan melalui perangkat lunak ini.

Perangkat lunak tersebut, yang didesain oleh Jon Harman, secara khusus didesain untuk menampakkan seni cadas yang telah pudar. Perangkat lunak itu berbentuk aplikasi yang dijalankan melalui program Image $\mathbf{J}$ yang dikembangkan oleh perusahaan perangkat lunak Java. Program Image J dapat diunduh dari Internet dan aplikasi Dstretch dapat diperoleh dengan menghubungi Jon Harman pada situs www.DStretch.com.

Secara khusus data yang dikumpulkan dalam penelitian ini disesuaikan dengan data Sauvet dkk. [2009] sehingga dapat ditempatkan bersamaan dengan data seni cadas dari kawasan lain di seluruh dunia untuk perbandingan. Data utama dalam penelitian ini adalah gambar binatang pada seni cadas prasejarah 
Sulawesi Selatan yang berdasarkan kajian terdahulu berupa gambar babi, anoa, ikan, burung, penyu, dan serangga [Eriawati 2003, BPCB Makassar 2013, Permana 2014].

Data keruangan secara kawasan mengenai persebaran gua tepat jenis binatang tertentu digambarkan juga dikumpulkan dalam penelitian ini. Permana [2014, 273] menyatakan bahwa di subkawasan Pangkep gambar binatang pada seni cadas lebih bervariasi, yakni babi, anoa, ikan, dan binatang melata, sedangkan di subkawasan Pangkep hanya terdapat gambar babi, di subkawasan Bone terdapat gambar babirusa dan anoa. Data keruangan gambar binatang per jenis pada seni cadas di Sulawesi Selatan akan dikumpulkan berdasarkan inventarisasi BPCB Makassar [2013] dan Direktorat Pelestarian Cagar Budaya dan Permuseuman [2014] serta penelitian lapangan oleh penulis ini.

Pengolahan data dilakukan dengan metode statistik Sauvet dkk. [2009, 4], yakni menghitung jumlah gambar per jenis binatang untuk menyusun pola frekuensi penggambaran binatang dalam seni cadas di Sulawesi Selatan. Data lokasi penggambaran per jenis binatang di dalam kawasan diolah untuk melihat pola persebaran gambar setiap jenis binatang di dalam kawasan seni cadas di Sulawesi Selatan. Sebagai contoh, pengolahan data gambar babi di seni cadas Sulawesi Selatan memberikan hasil sebagai berikut. Gambar babi dibandingkan segala jenis binatang yang digambarkan mencakup 30\% jenis binatang yang digambarkan dan digambarkan di 40\% dari keseluruhan lokasi gua-gua dengan gambar binatang.

Selain frekuensi dan persebaran, variabel lokasi gambar binatang juga digunakan untuk melengkapi data penelitian. Variabel lokasi gambar binatang. yaitu penempatan gambar binatang itu pada ruang gua (pintu masuk atau di dalam, lokasi yang terkena sinar matahari atau gelap, dinding yang tinggi atau rendah).

Pola frekuensi dan persebaran gambar binatang pada seni cadas di Sulawesi disusun ke dalam bentuk grafik yang dapat memperlihatkan kedua variabel. Grafik disusun mengikuti format Sauvet dkk. [2009] sehingga pola yang terlihat di seni cadas Sulawesi Selatan dapat dibandingkan dengan pola di kawasan seni cadas lain di dunia.

Pola arkeologis gambar binatang di kawasan karst Maros-Pangkep, yang diperoleh melalui tahap pengumpulan dan pengolahan data lebih lanjut, ditafsirkan berdasarkan pendapat para ahli dan data etnografi masyarakat tradisi seni cadas kontemporer di berbagai belahan dunia berdasarkan data Sauvet dkk. [2009] secara khusus dan kepustakaan lain mengenai bidang serupa secara umum.

Sauvet dkk. [2009] telah melakukan identifikasi pola arkeologis seni cadas binatang di kawasan seni cadas berdasarkan hasil penelitian di Benua Amerika, Australia, dan Afrika yang memiliki data etnografi. 
Secara umum, identifikasi itu menghasilkan pembagian konteks budaya seni cadas binatang dalam konteks totemisme, shamanisme, dan kehidupan sehari-hari. Penafsiran berdasarkan modifikasi metode yang ditawarkan oleh Sauvet dkk. [2009, 4] akan diterapkan pada pola arkeologis seni cadas binatang di kawasan karst Maros-Pangkep untuk menafsirkan apakah pola arkeologis yang dihasilkan dapat menunjukkan konteks budaya tertentu. Pola penggambaran binatang pada seni cadas di Sulawesi Selatan akan dibandingkan melalui grafik-grafik dengan pola penggambaran binatang pada seni cadas di berbagai belahan dunia dengan data Sauvet dkk. [2009].

\section{Analisis}

Berdasarkan pendataan lapangan dan kepustakaan terdapat 25 gua di tiga kabupaten di Provinsi Sulawesi Selatan yang memiliki penggambaran seni cadas dengan motif binatang di dalamnya. Gua itu adalah 10 gua di Kabupaten Maros masing-masing Leang Bulu Sipong 1, Leang Bulu Sipong 2, Leang Pattae, Leang Petta Kere, Leang Bara Tedong, Leang Jing, Leang Timpuseng, Leang Barugayya, Leang Batu Tianang, dan Leang Lambatorang.

Di Kabupaten Pangkajene Kepulauan (Pangkep) terdapat 13 gua, yaitu Leang Tuka 2, Leang Caddia, Leang Lompoa, Leang Kajuara, Leang Sakapao, Leang Ulu Tedong, Leang Lasitae, Leang Pamelakkang Tedong, Leang Bulu Bellang, Leang Garunggung, Leang Tagari, Leang Alla Masigi, dan Leang Sumpang Bita. Pada Kabupaten Bone terdapat 2 gua yaitu Leang Uhallie dan Leang Batti.

Peta persebaran situs dengan motif seni cadas pra-Austronesia dan motif seni cadas Austronesia menunjukkan bahwa tidak terdapat pola khusus yang membedakan wilayah kedua periode seni cadas itu. Oleh karena itu, diduga kuat bahwa perbedaan antara keduanya lebih dari segi temporal dibandingkan keruangan. Berikut adalah peta persebaran situs seni cadas dengan motif binatang di Sulawesi Selatan. 


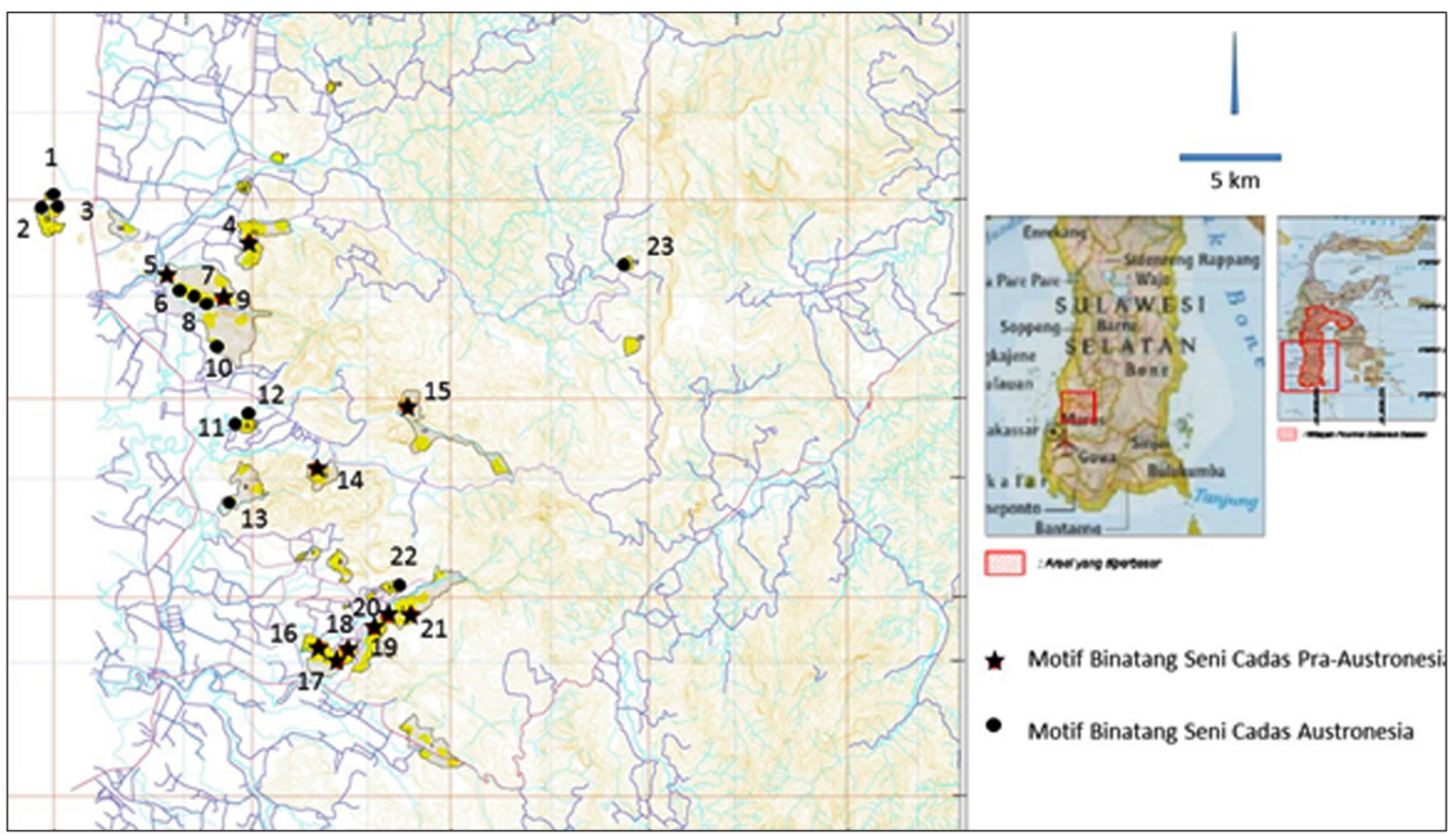

Keterangan:

1. Leang Pamelakkang Tedong 9. Leang Sakapao

2. Leang Lasitae

3. Leang Bulu Bellan

4. Leang Garunggung

5. Leang Tuka 2

6. Leang Caddia

7. Leang Lompoa

8. Leang Kajuara
10. Leang Ulu Tedong

11. Leang Bulu Sipong 1

12. Leang Bulu Sipong 2

13. Leang Batu Tianang

14. Leang Sumpang Bita

15. Leang Alla Masigi

16. Leang Jing
17. Leang Barugayya

18. Leang Timpuseng

19. Leang Pattae

20. Leang Petta Kere

21. Leang Bara Tedong

22. Leang Lambatorang

23. Leang Tagari

Peta 1. Persebaran Gua-Gua Motif Binatang pada Seni Cadas di Sulawesi Selatan (Modifikasi dari Peta Delineasi Kawasan Cagar Budaya Gua Prasejarah Kawasan Karst Maros-Pangkep, BPCB Makassar 2011).

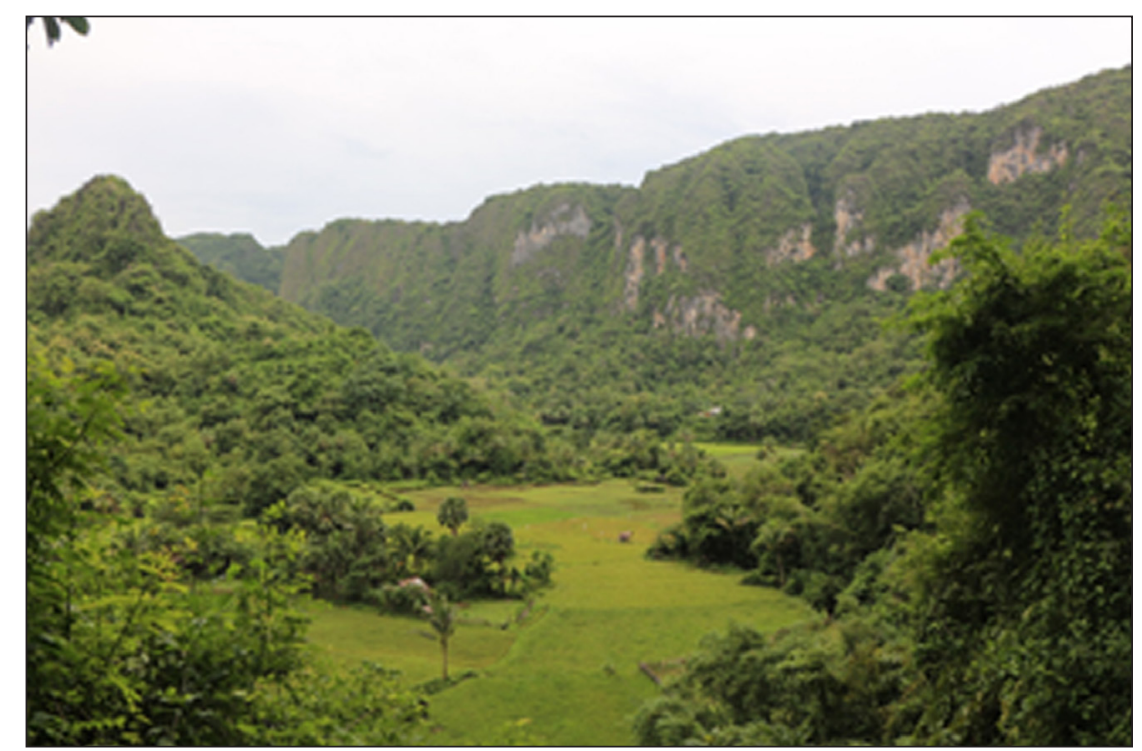

Foto 1. Perbukitan Karst di Kawasan Karst Maros-Pangkep. 
Gambar motif binatang periode Pra-Austronesia dapat ditemukan di Leang Pattae, Leang Petta Kere, Leang Bara Tedong, Leang Jing, Leang Timpuseng, Leang Barugayya di Kabupaten Maros; dan Leang Tuka 2, Leang Sakapao, Leang Garunggung, Leang Alla Masigi, dan Leang Sumpang Bita di Kabupaten Pangkep; serta Leang Uhallie dan Leang Batti di Kabupaten Bone. Pada umumnya gambar binatang yang dikelompokkan pada periode ini adalah motif mamalia besar, seperti babi (Sus celebensis) dan anoa (Bubalus depressicornis).

Motif binatang pada seni cadas periode Pra-Austronesia di Sulawesi Selatan terdiri dari tiga motif gambar binatang yaitu babi, burung, dan anoa. Frekuensi gambar binatang pada seni cadas periode PraAustronesia adalah babi $(71,4 \%)$, anoa $(21,5 \%)$, burung $(4,7 \%)$, dan ikan $(2,4 \%)$. Persebaran motif binatang pada seni cadas periode pra-Austronesia di Sulawesi Selatan adalah babi $(57,8 \%)$, anoa $(26,4 \%)$, ikan $(5,3 \%)$, dan burung (10,5\%). Berikut adalah tabel gua di Provinsi Sulawesi Selatan yang memiliki seni cadas motif binatang periode Pra-Austronesia.

\begin{tabular}{|c|c|c|c|c|c|c|}
\hline No. & Kabupaten & Sub kawasan & Nama Gua & Gambar Binatang & Warna & Jumlah \\
\hline 1. & Maros & Leang-leang & Leang Pattae & Babi & Merah & 1 \\
\hline 2. & Maros & Leang-leang & Leang Petta Kere & Babi & Merah & 2 \\
\hline 3. & Maros & Leang-leang & Leang Bara Tedong & Babi & Merah & 1 \\
\hline \multirow[t]{2}{*}{4.} & \multirow[t]{2}{*}{ Maros } & \multirow[t]{2}{*}{ Lopi-lopi } & \multirow[t]{2}{*}{ Leang Jing } & Burung & Merah & 1 \\
\hline & & & & Anoa & Merah & 1 \\
\hline 5. & Maros & Lopi-lopi & Leang Timpuseng & Babi & Merah & 1 \\
\hline 6. & Maros & Lopi-lopi & Leang Barugayya & Babi & Merah & 1 \\
\hline 7. & Pangkep & Bellae & Leang Tuka 2 & Babi & Merah & 1 \\
\hline 8. & Pangkep & Bellae & Leang Sakapao & Babi & Merah & 3 \\
\hline 9. & Pangkep & Siloro & Leang Garunggung & Babi & Merah & 1 \\
\hline \multirow[t]{3}{*}{10.} & \multirow[t]{3}{*}{ Pangkep } & \multirow[t]{3}{*}{ Balocci } & \multirow[t]{3}{*}{ Leang Alla Masigi } & Anoa & Merah & 1 \\
\hline & & & & Ikan & Merah & 1 \\
\hline & & & & Burung & Merah & 1 \\
\hline \multirow[t]{2}{*}{11.} & Pangkep & Sumpang Bita & Leang Sumpang Bita & Babi & Merah & 14 \\
\hline & & & & Anoa & Merah & 1 \\
\hline \multirow[t]{2}{*}{12.} & Bone & Bone & Gua Uhallie & Anoa & Merah & 5 \\
\hline & & & & Babi & Merah & 3 \\
\hline \multirow[t]{2}{*}{13.} & Bone & Bone & Gua Batti & Anoa & Merah & 1 \\
\hline & & & & Babi & Merah & 2 \\
\hline \multicolumn{5}{|r|}{ Total } & & 42 \\
\hline
\end{tabular}

Tabel 2. Gua dengan Motif Binatang Periode Pra-Austronesia. 
Frekuensi motif binatang pada periode pra-Austronesia menunjukkan bahwa babi adalah motif binatang yang paling sering digambarkan $(71,4 \%)$. Anoa adalah motif binatang kedua yang paling sering digambarkan $(21,5 \%)$ setelah babi. Pada kedua motif binatang itu, hampir semua berkonteks dengan gambar tangan. Berikut adalah beberapa motif binatang seni cadas pra-Austronesia di Sulawesi Selatan.
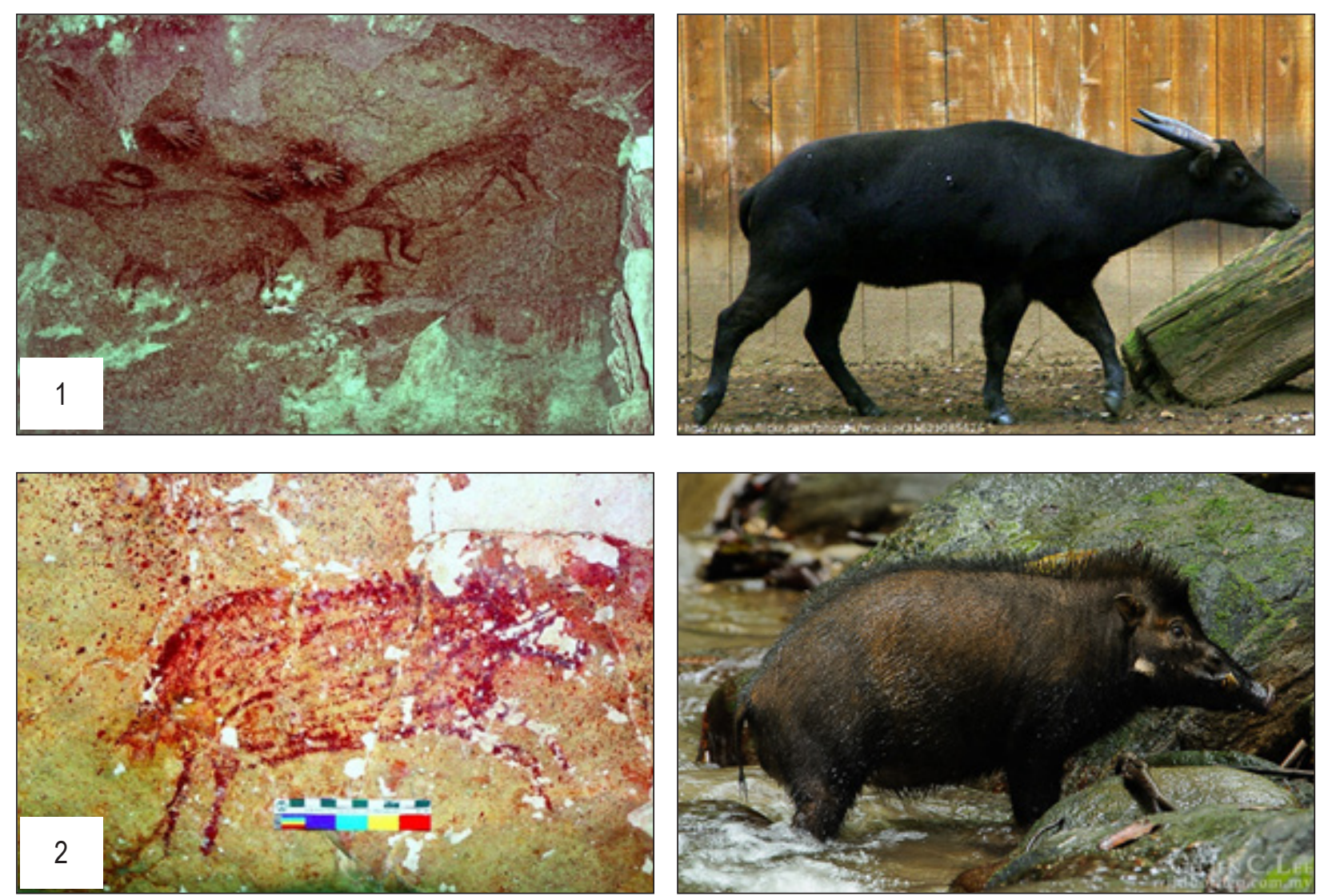

Keterangan:

1. Gambar Anoa di Leang Uhallie (Bone).

2. Gambar Babi di Leang Pattae (Maros).

Foto 2. Hasil Rekayasa Program Dstretch (Sumber: Foto Anoa: flickr.com dan Foto Babi: wildborneo.com.my).

Babi adalah motif binatang yang paling sering digambarkan di situs seni cadas periode praAustronesia (57,8\%), anoa adalah motif kedua yang paling sering digambarkan (26,4\%). Gambar ikan hanya tampak di satu situs, yaitu Leang Alla Masigi (Pangkep), burung hanya di Leang Jing (Maros) dan Leang Alla Masigi (Pangkep).

Perbandingan frekuensi gambar binatang dan persebaran motif binatang pada seni cadas periode Pra-Austronesia memperlihatkan bahwa babi adalah motif dominan sehingga kurvanya jauh ke kanan. Sementara itu, frekuensi motif lain terletak di sisi kiri grafik karena frekuensi dan persebarannya pada 
situs rendah. Berikut adalah grafik frekuensi dan persebaran motif binatang seni cadas pra-Austronesia di Sulawesi Selatan.

Motif binatang pada seni cadas periode Austronesia di Sulawesi Selatan terdiri dari sepuluh motif gambar binatang, yaitu ikan, pari manta, ubur-ubur, teripang, kuda, anjing, burung, biawak, penyu, dan ayam. Frekuensi gambar binatang pada seni cadas periode Austronesia adalah ikan (50\%), pari manta $(4,5 \%)$, ubur-ubur $(9 \%)$, teripang $(4,5 \%)$, kuda $(6,8 \%)$, anjing $(6,8 \%)$, burung $(2,2 \%)$, biawak $(4,5 \%)$, penyu (9\%), dan ayam (2,2\%). Persebaran gambar binatang pada seni cadas periode Austronesia adalah adalah ikan $(40 \%)$, pari manta (5\%), ubur-ubur (5\%), teripang (10\%), kuda (5\%), anjing $(5 \%)$, burung (5\%), biawak $(10 \%)$, penyu (10\%), dan ayam (5\%). Berikut adalah tabel gua di Provinsi Sulawesi Selatan yang memiliki seni cadas motif binatang periode Austronesia.

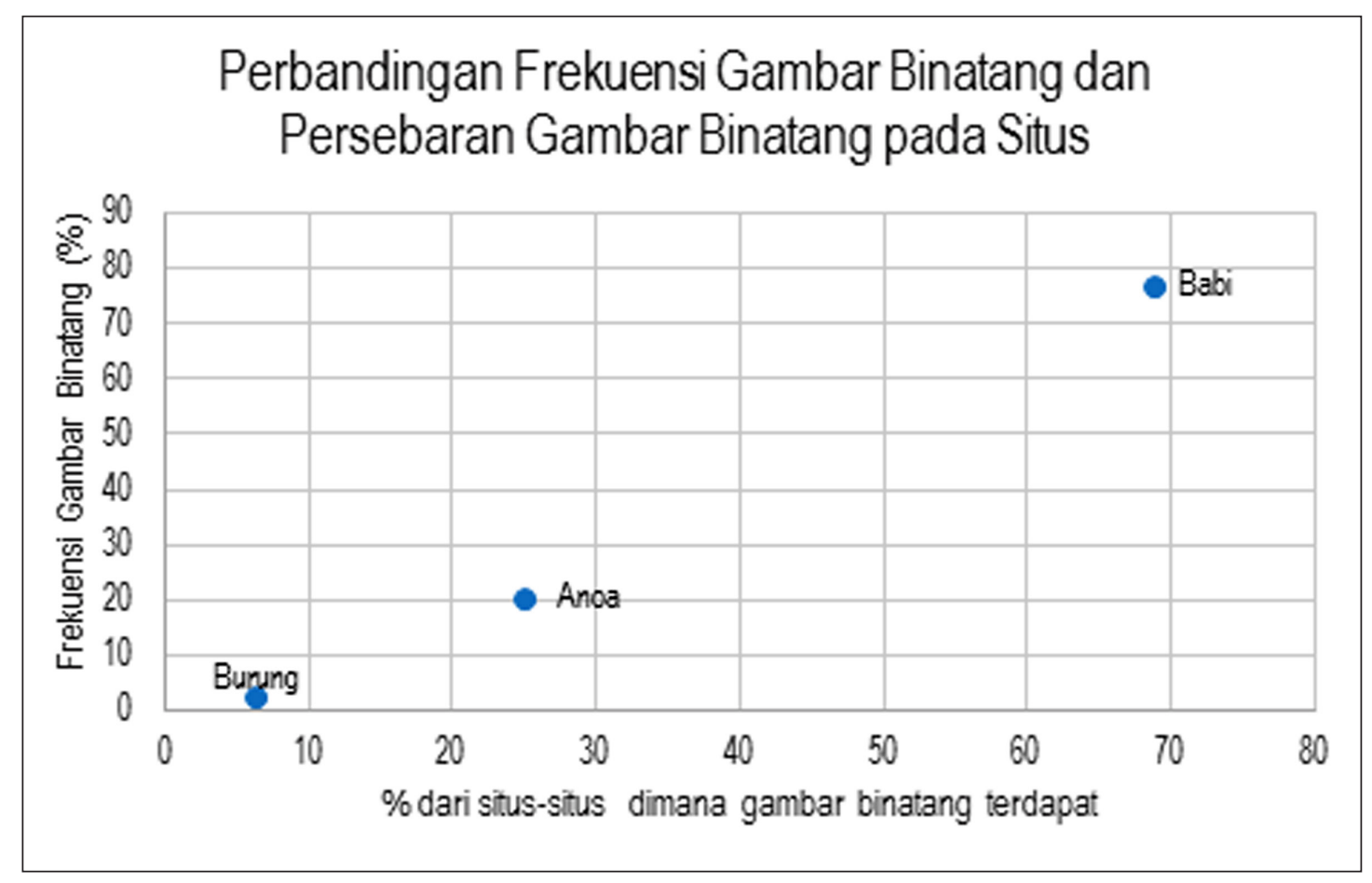

Grafik 1. Perbandingan Frekuensi dan Persebaran Motif Binatang Periode Pra-Austronesia di Sulawesi Selatan.

Berdasarkan frekuensi tersebut diketahui bahwa ikan adalah motif binatang yang paling sering digambarkan pada seni cadas periode Austronesia di Kawasan Karst Maros-Pangkep, Sulawesi Selatan. Ubur-ubur dan penyu adalah motif binatang kedua yang paling sering digambarkan setelah ikan. Hampir semua motif binatang itu berkonteks dengan gambar antropomorfis. Seni cadas periode Austronesia tidak terdapat di Leang Uhallie dan Leang Batti di Kabupaten Bone. 
Ikan adalah motif yang paling sering digambarkan di situs. Dari 12 situs yang diamati, terdapat delapan yang berisi motif ikan. Penyu dan teripang berada pada posisi kedua motif yang dominan digambarkan, yaitu terdapat di dua dari 12 situs yang diamati, sedangkan motif lain hanya digambarkan di satu situs. Berikut adalah beberapa motif binatang seni cadas periode Austronesia di Sulawesi Selatan.
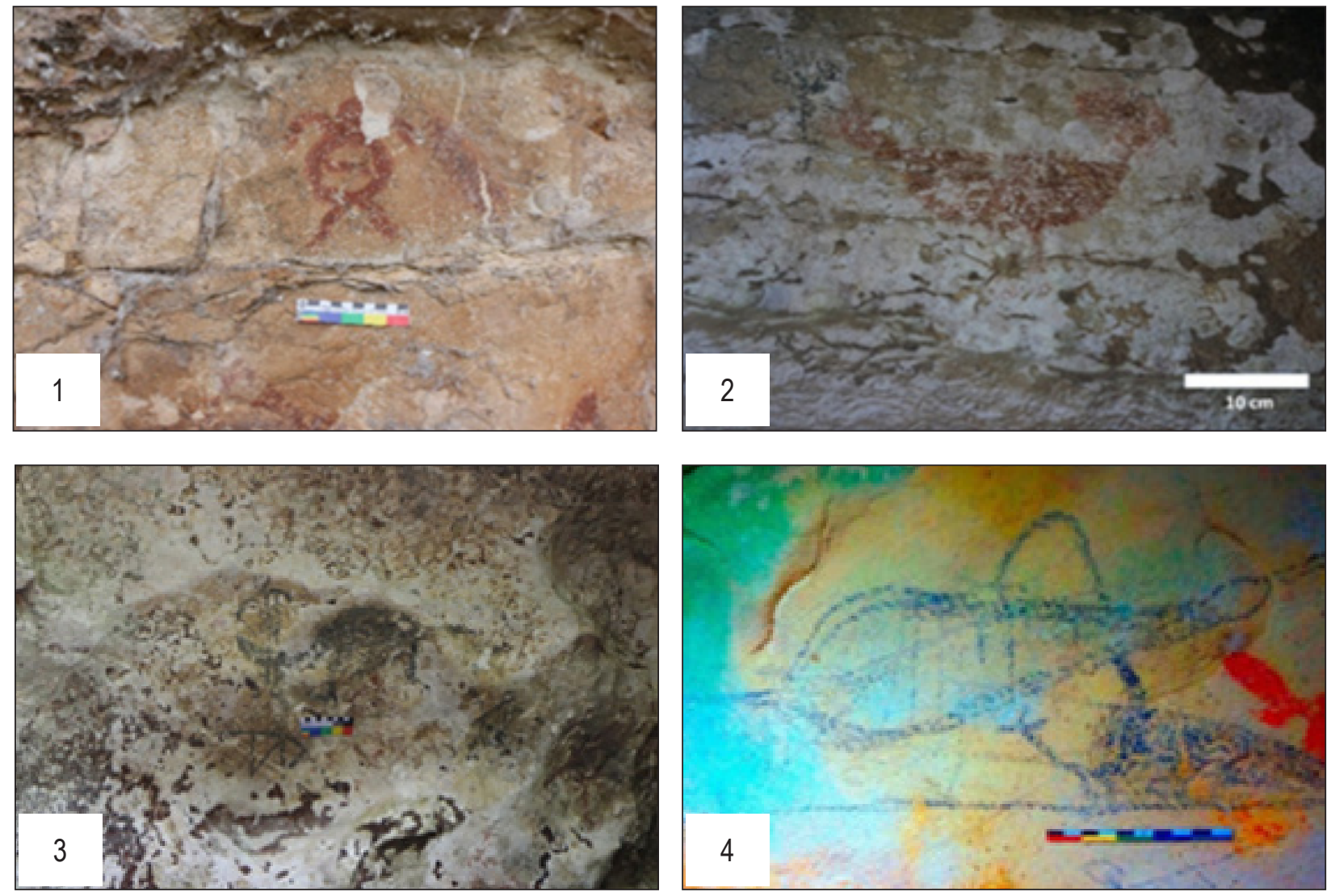

Keterangan:

1. Gambar Penyu di Leang Ulu Tedong (Pangkep). 3. Gambar Ayam di Leang Tagari (Pangkep).

2. Gambar Biawak di Leang Lompoa (Pangkep). 4. Gambar lkan di Leang Batu Tianang (Maros).

Foto 3. Motif-Motif Binatang Periode Austronesia.

Perbandingan frekuensi gambar binatang dan persebaran motif binatang pada seni cadas periode Austronesia memperlihatkan bahwa ikan adalah motif dominan sehingga kurvanya jauh ke kanan. Sedangkan frekuensi motif lain terletak di sisi kiri grafik karena frekuensi dan persebarannya pada situs-situs rendah. Berikut adalah grafik frekuensi dan persebaran motif binatang seni cadas periode Austronesia di Sulawesi Selatan. 


\begin{tabular}{|l|l|l|l|l|c|}
\hline No & Kabupaten & Sub kawasan & Nama Gua & Gambar Binatang & Jumlah \\
\hline 1. & Maros & Bulu Sipong & Leang Bulu Sipong 1 & Ikan & 1 \\
\cline { 5 - 6 } & & & & Pari Manta & 2 \\
\hline 2. & Maros & Bulu Sipong & Leang Bulu Sipong 2 & Ikan & 5 \\
\hline 3. & Maros & Rammang-Rammang & Leang Batu Tianang & Ikan & 3 \\
\hline 4. & Maros & Lambatorang & Lambatorang & Kuda & 3 \\
\cline { 5 - 6 } & & & & Anjing & 3 \\
\hline 5. & Pangkep & Bellae & Leang Caddia & Burung & 1 \\
\hline 6. & Pangkep & Bellae & Lang Lompoa & Biawak & 1 \\
\hline 7. & Pangkep & Bellae & Leang Kajuara & Ikan & 1 \\
\hline 8. & Pangkep & Bellae & Leang Ulu Tedong & Penyu & 2 \\
\hline & & & & Ikan & 2 \\
\hline 9. & Pangkep & Labakkang & Leang Lasitae & Ikan & 5 \\
\hline & & & & Teripang & 1 \\
\hline 10. & Pangkep & Labakkang & Leang Pamelakkang Tedong & Ikan & 2 \\
\hline 11. & Pangkep & Labakkang & Leang Bulu Bellang & Penyu & 2 \\
\hline & & & & Ikan & 3 \\
\hline 12 & Pangkep & Tagari & Leang Tagari & Ayam & 1 \\
\hline & & & & Biawak & 1 \\
\hline & & & & & 44 \\
\hline
\end{tabular}

Tabel 2. Gua dengan Motif Binatang Periode Austronesia.

Pada periode pra-Austronesia, motif binatang pada seni cadas didominasi oleh gambar binatang mamalia besar, terutama babi dan anoa, yang tersebar hampir di semua situs. Sementara itu, pada periode Austronesia, motif binatang yang digambarkan lazimnya binatang laut, seperti ikan, ubur-ubur, teripang, dan penyu.

Frekuensi dan persebaran motif binatang pada seni cadas di Sulawesi Selatan di atas akan dibandingkan dengan frekuensi dan persebaran motif binatang pada tiga tradisi seni cadas etnografis yang menunjukkan konteks budaya shamanisme, totemisme, dan kehidupan sehari-hari menggunakan data Layton [2000]. Ketiga sampel yang mewakili tiga tradisi itu adalah (1) Totemisme diwakili oleh kawasan seni cadas Kimberley Barat (Australia), (2) Shamanisme direpresentasikan oleh data kawasan Northern Cape (Afrika Selatan) oleh Deacon [1994], dan (3) Kehidupan sehari-hari direpresentasikan oleh seni cadas Laura di Queensland Utara (Australia) [Sauvet et al. 2009, 4-5]. Berdasarkan gabungan data seni cadas di Sulawesi Selatan dan tiga tradisi itu, diperoleh grafik perbandingan frekuensi dan persebaran motif binatang seni cadas sebagai berikut. 


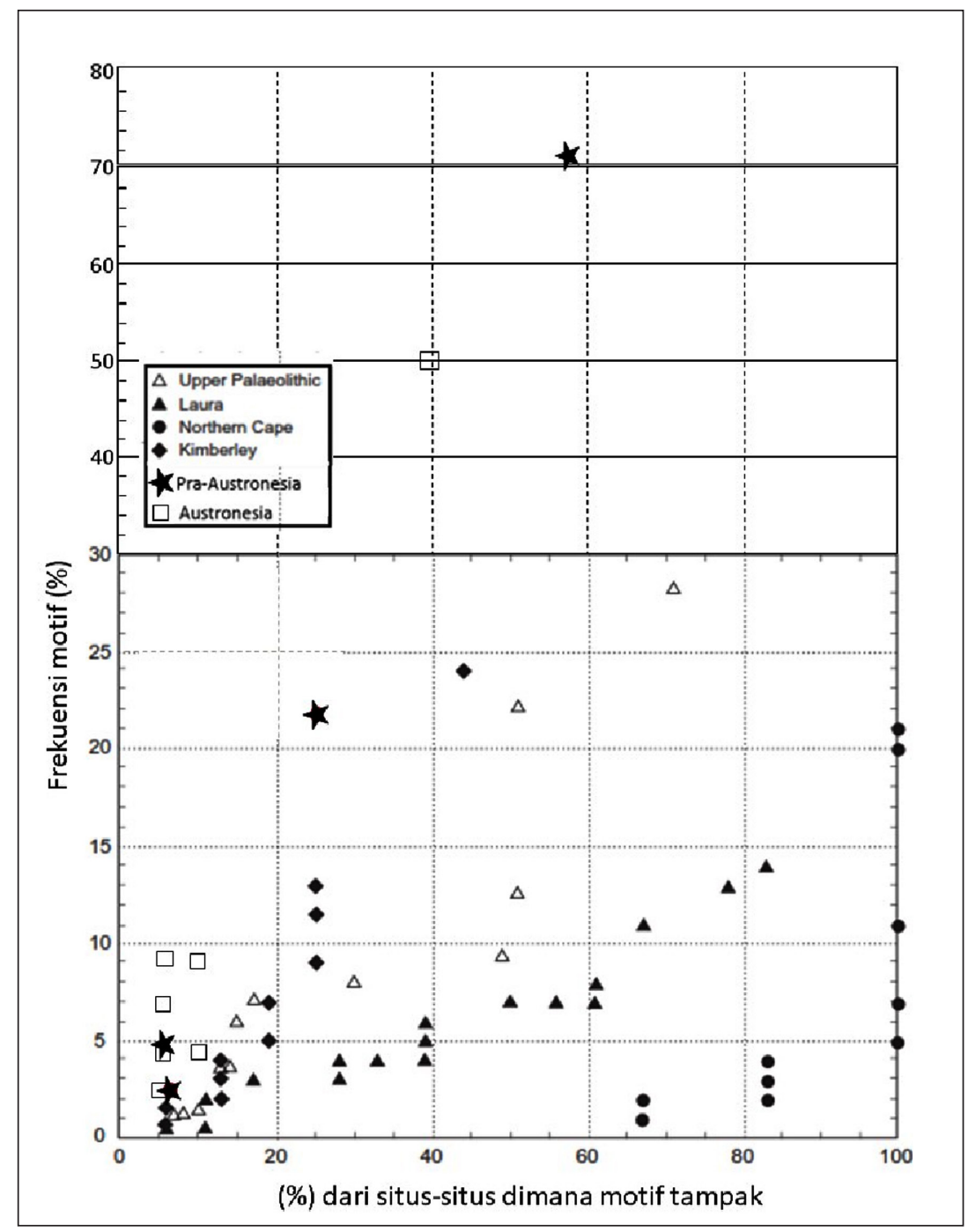

Grafik 3. Perbandingan Frekuensi dan Persebaran Motif Binatang Seni Cadas di Sulawesi Selatan Modifikasi dari Figur 2 (Sauvet et al. 2009,5).

Setiap titik data pada Grafik 3 merepresentasikan spesies binatang tertentu yang dikodifikasi berdasarkan kawasan seni cadas tertentu. Grafik menunjukkan bahwa metode membedakan secara jelas antara tiga kasus kontemporer, artinya setiap kasus menggambarkan satu dari empat tabel pada model (Tabel 1).

Pada kasus etnografi tempat binatang berfungsi sebagai totem klan (Kimberley) kurva terbatas pada bagian kiri grafik karena setiap spesies digambarkan pada proporsi yang rendah di berbagai situs. Motif yang paling banyak digambarkan dan tersebar di situs, kategori umum "ular", tampak pada 44\% dari situs. Pada ujung yang lain, kurva yang menunjukkan kemungkinan kasus shamanisme, Northern Cape (Afrika Selatan), tergambar pada bagian setengah-kanan pada grafik, karena semua spesies digambarkan pada proporsi yang tinggi. Lima motif yang paling banyak digambarkan tampak di semua situs. Kurva untuk motif 
yang kemungkinan menggambarkan seni sekuler di Distrik Laura, Queensland Utara (Australia) terletak antara dua kasus kontemporer karena banyak spesies yang digambarkan dan banyak yang digambarkan pada proporsi yang besar dari situs. Ketiga kurva mengikuti prediksi dari model. Kurva untuk Palaeolitik Atas terletak antara contoh kasus Western Kimberley dan Laura, tetapi relatif jauh dari kurva seni shamanik [Sauvet et al. 2009, 5].

Kurva seni cadas Sulawesi Selatan pada periode pra-Austronesia didominasi oleh gambar babi yang terletak jauh pada sisi kanan kurva menyerupai kasus etnografis yang merepresentasikan shamanisme di Northern Cape (Afrika Selatan). Akan tetapi, berdasarkan perbandingan itu, diketahui bahwa penggambaran babi pada seni cadas periode pra-Austronesia di Sulawesi Selatan tidak memiliki perbandingan yang sama dengan contoh kasus lain. Pada kasus lain, tidak ditemukan penggambaran binatang dengan frekuensi yang sangat tinggi seperti halnya penggambaran babi itu.

Pada periode Austronesia, kurva seni cadas di Sulawesi Selatan terletak di kurva bagian kiri grafik menyerupai contoh kasus Kimberley (Australia): setiap spesies digambarkan pada proporsi yang rendah di situs. Kimberley merupakan contoh kasus seni cadas yang memiliki konteks budaya totemisme. Akan tetapi, motif yang paling banyak digambarkan dan tersebar di situs pada periode Austronesia di Sulawesi Selatan adalah bentuk ikan (50\%), sementara motif yang paling banyak digambarkan dan tersebar di situs di kawasan Kimberley, Australia, adalah kategori umum "ular" yang tampak pada 44\% dari situs [Sauvet dkk. $2009,5]$. Frekuensi ikan yang dominan (50\%) pada seni cadas periode Austronesia di Sulawesi Selatan juga tidak dijumpai pada contoh kasus lain selain contoh kasus periode pra-Austronesia di kawasan yang sama.

Lebih lanjut frekuensi dan persebaran motif binatang pada seni cadas di Sulawesi Selatan akan dibandingkan dengan data yang lebih luas mengenai frekuensi motif binatang pada seni cadas dari berbagai belahan dunia yang telah dirangkum oleh Sauvet dkk. [2009]. Berdasarkan perbandingan itu, diharapkan konteks budaya motif binatang pada seni cadas di Sulawesi Selatan terlihat.

Data pertama dari dua studi etnografi lebih jauh adalah dari Western Arnhem Land, Australia sebagai contoh lain dari seni sekuler. Figur digambarkan dengan teknik yang disebut "X-ray" detail, yaitu penggambaran realistis dari organ dalam dan jaringan, yang diidentifikasikan oleh seniman-seniman lokal sebagai rekaman kegiatan mengumpulkan makanan, atau "hanya daging" ("just meat") [Taylor 1996, 17 20]. Instruktur Aborigin narasumber Taçon menunjukkan kepadanya bagaimana selusin spesies ikan yang 
berbeda digambarkan secara hati-hati dengan beberapa detail anatomis bersamaan dengan spesies lain termasuk kadal dan penyu [Taçon 1988].

Kasus etnografi yang kedua adalah di Sungai Stein, British Kolombia (Kanada). Kawasan kecil di dataran tinggi Kolombia itu memiliki keuntungan karena terdapat dokumentasi etnografi dalam jangka waktu lama, dimulai dari James Teit [1918], yang telah membimbing ekspedisi Boas-Jessup, dan dilengkapi oleh informasi dari Annie York antara 1989 dan 1991 [York et al. 1993], yang menunjukkan bahwa seni cadas diasosiasikan baik dengan roh dalam bentuk binatang yang dicari pada saat inisiasi kedewasaan melalui pencarian penglihatan dari dunia roh melalui berbagai tantangan fisik dan mental (adolescent vision quest), maupun aktivitas shaman profesional.

Data Palaeolitik Atas telah sangat banyak dilengkapi menggunakan data yang dikumpulkan oleh Sauvet dan Wlodarczyk. Data itu telah dibedakan menjadi subkawasan yang dapat diterapkan analisis spasial dan diakronik. Sauvet dan Wlodarzczyk [2000] menjelaskan mengapa mereka membagi seni cadas Palaeolitik Atas hanya ke dalam dua periode; periode arkaik yang membentang dari Masa Aurignacian sampai awal Masa Magdalenian, dan periode selanjutnya yang melingkupi masa Magdalenian Pertengahan sampai Atas. Pertanggalan C14 menempatkan periode itu pada kurun waktu sekitar 15.000 tahun yang lalu. Dua periode itu berkorespondensi kurang lebih sama dengan fase yang disebut Leroi-Gourhan [1965] sebagai Style II dan Style III untuk yang pertama, dan Style IV untuk yang kedua.

Kasus arkeologi tambahan pada Sauvet dkk. [2009] yaitu (1) Seni Cadas Ndedema Gorge, sebuah lembah kecil di utara Pegunungan Drakensberg (Afrika Selatan) yang didokumentasikan oleh Pager [1971], (2) Seni Cadas High Brandberg di Namibia, yang juga didokumentasikan oleh Pager [1989 sampai 2000], Lenssen-Erz [2001] dan Richter [1991] yang mempertimbangkan bahwa seni cadas di High Brandberg (Daureb di Bahasa Tradisional Khoekhoegowab) (Namibia), timbul dari sebagian besar konteks sekuler dimana springbok (Antidorcas marsupialis), motif yang dominan, mungkin menggambarkan banyaknya populasi binatang itu pada saat dan setelah musim penghujan, dan (3) Seni Cadas Gaya Dinamis Arnhem Land (Australia) yang mendahului tradisi yang disebut "X-ray". Ketiadaan binatang laut dan pesisir, dan kehadiran gambar bumerang, yang kini hanya digunakan di selatan Arnhem Land, telah diinterpretasi oleh Lewis [1988] dan para arkeolog lain sebagai bukti bahwa Seni Cadas Gaya Dinamis digambarkan ketika periode musim kering (aridity), ketika Arnhem Land jauh dari pantai utara Australia, kemungkinan sepanjang periode glasial akhir (110.000-12.500 tahun yang lalu). Baik Lewis [1988] dan Taçon \& Chippindale 
[2008, 81], menghubungkan asal mula seni "X-ray" dengan terbentuknya dataran basah di pesisir yang ekstensif lebih dari 1500 tahun yang lalu, dan (4) Seni Cadas Ennedi (Chad), yang adalah satu-satunya kasus seni cadas yang tidak dibuat oleh pemburu-pengumpul makanan. Seni cadas memiliki karakter, yaitu menggambarkan fokus pada hewan ternak domestik, yang digambarkan pada semua situs. Tampaknya seni itu mengekspresikan perilaku penggembala (cattle-centred) dan ideologi yang berhubungan dengan "cattle complex", artinya kepemilikan hewan ternak memiliki nilai budaya lebih dari sekadar nilai ekonomi yang sederhana [Herskovits 1926].

Sauvet dkk. $[2009,10]$ mencoba untuk menempatkan hanya motif yang paling sering muncul, tetapi menemukan bahwa karakteristiknya dapat tidak tampak jika digambarkan dengan satuan (single), situs yang tidak representatif (atypical) dan memutuskan untuk melakukan kompromi dengan menempatkan setiap kasus dengan poin yang merepresentasikan distribusi rata-rata dari dua spesies yang paling banyak digambarkan. Perbandingan motif binatang seni cadas di Sulawesi Selatan dengan data dunia itu dapat dilihat pada grafik 4 .

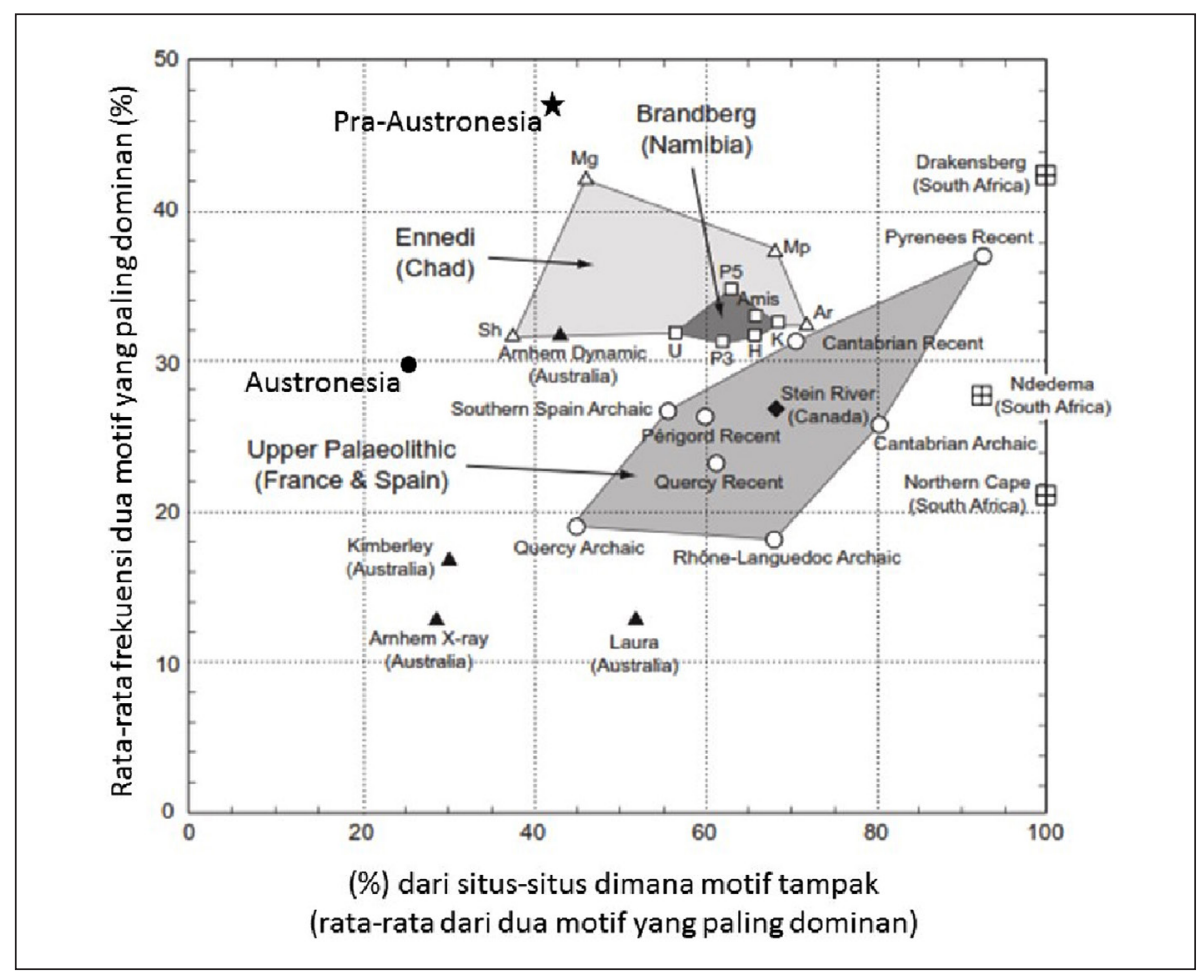

Grafik 4. Perbandingan Frekuensi dan Persebaran Motif Binatang Seni Cadas di Sulawesi Selatan dengan Data Dunia (Modifikasi dari Figur 3 [Sauvet et al. 2009, 10]).

Grafik 4 menunjukkan bahwa seni cadas periode Austronesia di Sulawesi Selatan terletak dekat dengan kasus seni cadas Kawasan Shekitiye, Ennedi (Chad) dan Seni Cadas Dinamis Arnhem Land 
(Australia) yang menunjukkan dominasi satu motif binatang (ikan pada periode Austronesia Sulawesi Selatan, sapi pada seni cadas Ennedi (Chad), dan makropod pada seni cadas dinamis Arnhem Land). Letak seni cadas totemik Western Kimberley juga rendah pada grafis, berhubungan dengan fakta bahwa bahkan motif binatang yang paling banyak digambarkan memiliki frekuensi rendah. Sementara dua spesies binatang yang paling banyak digambarkan terdapat pada proporsi yang lebih rendah pada situs di Western Kimberley dibandingkan dengan di Laura (berkorespondensi dengan prediksi-prediksi model), dua spesies binatang yang paling umum digambarkan tidak lagi tersebar secara luas di Western Arnhem Land dibandingkan dengan binatang di Kimberley (berlawanan dengan prediksi model) [Sauvet dkk. 2009, 10].

Pola persebaran motif binatang selama masa Palaeolitik Atas bervariasi baik dalam ruang maupun waktu, tetapi variasi yang direpresentasikan oleh -sampel yang lebih besar terletak di antara sebagian besar kasus etnografi. Selama fase "arkaik" seni Palaeolitik Kawasan Rhône-Languedoc dan Quercy (Prancis) mendekati struktur seni cadas totemisme dan kehidupan sehari-hari, yaitu tidak ada satu motif yang mendominasi, sementara di Iberian Peninsula (Andalucia dan Cantabria) (Spanyol) dan Périgord (Prancis) condong ke struktur seni cadas shamanisme, berdasarkan dominasi satu motif [Sauvet dkk. 2009, 10].

Spesies dominan yang digambarkan di Spanyol adalah rusa merah (Cervus elaphus) terutama betina dan di Périgord (Prancis) adalah kuda. Pada awal masa Magdalenian Pertengahan $( \pm 12.500$ tahun yang lalu), tampaknya terdapat konvergensi budaya (cultural convergence) antara Cantabria dan Pyrenees sehingga struktur seni cadas menunjukkan lebih dekat kepada shamanisme. Sekarang mereka berbagi motif binatang yang paling banyak digambarkan, yaitu bison. Périgord tampak terpinggirkan pada saat ini, tetapi keadaan itu berhubungan dengan peningkatan jumlah gambar mammoth di beberapa situs. Jika tidak karena jumlah besar gambar mammoth di situs, kuda dan bison akan menjadi motif dominan seperti halnya di kawasan lain, dan posisi Périgord pada grafik 3.2 akan terletak lebih dekat kepada Cantabria dan Pyrenees [Sauvet et al. 2009, 10-11].

Seni cadas periode pra-Austronesia di Sulawesi Selatan terletak berdekatan dengan tiga studi kasus arkeologi yang lain (Seni Dinamis Arnhem Land, Daureb/High Brandberg, dan seni pastoralis Ennedi) seluruhnya terletak di bagian setengah atas grafik, di atas jangkauan kasus Palaeolitik Atas dan bahkan jauh dari kasus etnografi. Sementara itu, struktur seni cadas periode pra-Austronesia di Sulawesi Selatan terletak dekat dengan struktur seni cadas Mornou di Kawasan Ennedi, Chad. Dominannya satu motif binatang, 
seperti halnya babi, pada seni cadas periode pra-Austronesia di Sulawesi Selatan menunjukkan struktur seni cadas shamanisme.

\section{Kesimpulan}

Struktur seni cadas motif binatang periode pra-Austronesia di Sulawesi Selatan didominasi oleh satu spesies binatang, yaitu babi liar Sulawesi (Sus celebensis), hingga $71 \%$ dari keseluruhan situs. Struktur budaya seni cadas yang berkaitan dengan gambar tangan diduga kuat berkembang pada periode yang panjang: dari gambar babi yang tertua di Leang Timpuseng, Maros (35 ribu tahun yang lalu), gambar babi di Leang Barugayya, Maros (30 ribu tahun yang lalu) hingga pertanggalan termuda dari gambar tangan di Leang Jing, Maros (17 ribu tahun yang lalu).

Penggambaran babi di seni cadas periode pra-Austronesia di Sulawesi Selatan bervariasi dalam bentuk dan ukuran. Terdapat penggambaran babi dalam bentuk naturalis, penggambaran bagian kepala saja, dan penggambaran babi dalam bentuk simbolis: sering kali tubuh babi digambarkan menggelembung. Penggambaran serupa juga dilakukan pada anoa.

Struktur seni cadas tersebut memiliki daerah persebaran yang luas di kawasan karst di tiga kabupaten, yaitu Maros, Pangkep, dan Bone di Provinsi Sulawesi Selatan. Kawasan karst itu tersebar mulai dari pesisir barat Sulawesi Selatan (Leang Garunggung, Leang Tuka 2, dan Leang Sakapao di Kabupaten Pangkep) hingga ke daerah pedalaman (Leang Timpuseng, Pettae, dan Petta Kere di Kabupaten Maros, Leang Sumpang Bita di Kabupaten Pangkep, serta Leang Uhallie dan Batti di Kabupaten Bone).

Berdasarkan hasil pertanggalan yang menempatkan seni cadas periode pra-Austronesia di Sulawesi Selatan dalam kurun waktu \pm 35 ribu tahun yang lalu, diduga kuat dominasi gambar babi pada struktur seni cadas itu adalah gejala budaya masyarakat pemburu-pengumpul makanan. Bukti itu diperkuat dengan penggambaran anoa yang di beberapa situs bersamaan dengan gambar babi karena diketahui bahwa anoa adalah binatang liar yang tidak didomestikasi.

Salah satu alternatif pilihan interpretasi untuk struktur tersebut adalah shamanisme, dengan masyarakat pemburu-pengumpul makanan yang mengutamakan satu jenis binatang dalam struktur seni cadasnya. Contoh arkeologis yang sama juga terdapat pada keutamaan bison pada seni cadas Magdalenian di Pegunungan Pirenia yang sangat jelas dapat dibandingkan dengan religi tempat bison memiliki peran utama. Kasus etnografi adalah shamanisme menjadi struktur seni cadas dalam penggambaran eland pada 
seni cadas masyarakat Maluti San di Drakensberg (Afrika Selatan). Shamanisme juga terdapat pada seni cadas dari 1500 tahun terakhir di Coso Ranges, California Timur (Amerika Serikat) dimana 51\% dari pahatan di Coso Ranges menggambarkan domba gunung, diikuti dengan 29\% gambar berbagai pola geometris. Kasus lain di luar seni cadas dapat ditemukan dalam etnografi yang mengasosiakan shamanisme dengan spesies utama, seperti halnya jaguar di dataran rendah Amerika Selatan atau beruang di Siberia.

Struktur motif binatang seni cadas periode Austronesia di Sulawesi Selatan didominasi penggambaran motif ikan (50\%). Penggambaran binatang pada periode itu didominasi oleh binatang laut, yaitu ikan, penyu, teripang, ubur-ubur dan hewan domestik, yaitu ayam, kuda, dan anjing. Gambar bercorak maritim itu berkonteks dengan gambar antropomorfis yang digambarkan dalam gaya dinamis atau gambar geometris. Salah satu penggambaran binatang pada periode itu, yang dapat menjadi pertanggalan relatif, adalah penggambaran ayam jago pada Leang Tagari (Pangkep), yaitu 3000 tahun yang lalu.

Pada seni cadas periode Austronesia terdapat motif antropomorfis dan geometris yang jarang dijumpai pada periode pra-Austronesia di Sulawesi Selatan. Seni cadas periode Austronesia di Sulawesi Selatan diduga kuat dikembangkan oleh masyarakat yang telah mengenal budi daya dan struktur sosial yang hierarkis. Penggambaran antropomorfis yang memiliki kaki, seperti ayam, dan menggunakan hiasan kepala menyerupai antena serangga di Leang Ulu Tedong dan Leang Pamelakkang Tedong, Pangkep diduga kuat memiliki konteks budaya yang terkait dengan religi.

Penggambaran motif binatang laut/pesisir pada periode tersebut mungkin berkaitan dengan masa ketika kawasan karst Maros-Pangkep terletak dekat dengan garis pantai barat Sulawesi Selatan. Penggambaran motif binatang laut juga sering kali berkaitan dengan gambar perahu dan gambar antropomorfis dalam gaya dinamis yang menunjukkan kegiatan maritim, seperti naik perahu, berburu ikan, dan menjala. Dominannya penggambaran ikan $(50 \%)$ pada seni cadas periode itu, selain menunjukkan gambaran kehidupan nelayan masyarakat pendukungnya, juga diduga kuat menggambarkan nilai sosioreligi bagi masyarakatnya. Ikan diduga kuat tidak hanya dipandang sebagai objek atau buruan layaknya bahan makanan pada masyarakat modern, tetapi juga sebagai subjek yang dapat memengaruhi kehidupan manusia.

Penggambaran adegan perburuan ikan dengan harpun pada seni cadas di Leang Bulu Sipong 1 (Maros) menunjukkan bahwa masyarakat pendukungnya melakukan perburuan ikan besar. Perburuan ikan besar dengan harpun seperti itu pada umumnya dilakukan di lepas pantai dan merupakan perjalanan 
perburuan yang sangat sulit, bahkan di zaman modern. Berdasarkan fakta itu, diduga kuat penggambaran ikan pada seni cadas periode Austronesia bersifat sosio-religi yang mungkin menunjukkan kasus shamanisme.

\section{Saran}

Data gambar binatang pada seni cadas di Sulawesi Selatan, dalam penelitian ini, dikumpulkan dengan metode lapangan dan kepustakaan yang dikumpulkan dalam jangka waktu enam bulan sesuai dengan waktu studi penulis ini. Data itu tentu saja di kemudian hari dapat ditambah jika ada temuan baru atau data yang belum termuat dalam penelitian ini. Data juga dapat berkurang jika terdapat gambar binatang yang rusak dan tidak dapat diamati lagi. Tentunya berdasarkan data yang terus-menerus diperbaharui, konteks budaya gambar binatang pada seni cadas di Sulawesi Selatan dapat diketahui lebih lanjut.

Data gambar binatang pada seni cadas di wilayah lain di Indonesia yang dapat digunakan untuk dianalisis menggunakan metode frekuensi dan persebaran menurut Sauvet dkk. [2009] belum tersedia. Meskipun tanpa keterangan etnografi, data frekuensi dan persebaran gambar binatang pada kawasan seni cadas di Indonesia dapat menampakkan konteks budaya seni cadas itu bagi masyarakat pendukungnya.

\section{Daftar Referensi}

Aubert, Maxime, et al. 2014. Pleistocene cave art from Sulawesi, Indonesia. Nature 514 (Oktober): 223-227. DOl:10.1038/nature13422.

Balai Pelestarian Cagar Budaya (BPCB) Makassar. 2011. Laporan Zonasi Gua-Gua Prasejarah Kabupaten Pangkep. Makassar. Kementerian Pendidikan dan Kebudayaan.

2013. Naskah Usulan Penetapan Satuan Ruang Geografis Gua Prasejarah Maros-Pangkajene dan Kepulauan. Tidak diterbitkan.

Berrocal, Maria Cruz. 2011. Analogical Evidence and Shamanism in Archaeological Interpretation: South African and European Palaeolithic Rock Art. Dalam Norwegian Archaeological Review Volume 44, Issue 1 (Juni). http://www.tandfonline.com/doi/full/10.1080/00293652.2011.572672(diakses 5 Desember 2015).

Deacon, J. 1994. Rock engravings and the folklore of Bleek and Lloyd's /Xam San informants. Dalam Contested Images: Diversity in Southern African Rock Art Research, diedit oleh T. Dowson dan D. LewisWilliams, 237-56. Johannesburg: Witwatersrand University Press. 
Eriawati, Yusmaini. 2003. Album Seni Budaya; Lukisan di Gua-Gua Karst Maros-Pangkep Sulawesi Selatan; Gambaran Penghuni dan Matapencahariannya. Jakarta: Deputi Bidang Pelestarian dan Pengembangan Kebudayaan, Kementerian Kebudayaan dan Pariwisata.

Fage, Luc-Henri, Jean-Michel Chazine, dan Pindi Setiawan. 2010. Borneo Menyingkap Gua Prasejarah. Diterjemahkan oleh Rahayu Surtiati Hidayat. Jakarta: Le Kalimanthrope.

Grant, Jim, Sam Gorin, dan Neil Fleming. 2001. The Archaeology Coursebook: an Introduction to Study Skills, Topics, and Methods. London: Routledge.

Hartley, R. J. 1992. Rock Art on the Northern Colorado Plateau. Aldershot: Avebury.

Herskovits, M. J. 1926. The cattle complex in East Africa. American Anthropologist 28, 230-72.

Fadhlan S. Intan. 2008. Quaternary Geology of Sulawesi. Dalam Austronesian in Sulawesi, diedit oleh Truman Simanjuntak, 9-22. Yogyakarta: Galangpress.

Laming-Emperaire, Anette. 1962. La Signification de l'Aart Rupestre Paléolithique. Paris: Editions A. \& J. Picard.

Layton, Robert. 1995. Rereading rock art: text and discourse. Dalam Perceiving Rock Art: Social and Political Aspects, diedit oleh K. Helskog \& B. Olsen, 217-27. Oslo: Novus forlag. 2000. Shamanism, Totemism and Rock Art: "Les Chamanes de la Préhistoire" in the Context of Rock Art Research. Cambridge Archaeological Journal 10(1), 169-86.

Lenssen-Erz, Tilman. 2001. Gemeinschaft - Gleichheit - Mobilität. Felsbilder im Brandberg, Namibia und ihre Bedeutung. Cologne: Heinrich-Barth-Institut.

Leroi-Gourhan, André. 1965. Treasures of Prehistoric Art. Diterjemahan oleh Norbert Guterman. New York: Harry Abrams.

Lewis-Williams, David. 1981. Believing and Seeing: Symbolic Meanings in Southern San Rock Paintings. London: Acedemic Press. 1988. The Rock Paintings of Arnhem Land: Social, Ecological and Material Culture Change in the Post-Glacial Period. British Archaeological Reports 145. Oxford: BAR.

Pager, H. 1971. Ndedema Gorge: a Documentation of the Rock Paintings of the Ndedema Gorge. 2 jilid. Graz: Akademische Druck- und Verlagsanstalt. . 1989. The Rock Paintings of the Upper Brandberg, part 1: Amis Gorge. 2 jilid. Cologne: Heinrich-Barth Institut. 
The Rock Paintings of the Upper Brandberg, part 2: Hungorob Gorge. 2jilid. Cologne: HeinrichBarth-Institut. 1995. The Rock Paintings of the Upper Brandberg, part 3: The Southern Gorges. 2 jilid. Cologne: Heinrich-Barth-Institut. 1998. The Rock Paintings of the Upper Brandberg, part 4: Umuab and Karoab Gorges. 2 jilid. Cologne: Heinrich-Barth-Institut. 2000. The Rock Paintings of the Upper Brandberg, part 5: Naib Gorge $(A)$ and the Northwest. 2 jilid. Cologne: Heinrich-Barth-Institut.

R. Cecep Eka Permana. 2014. Gambar Tangan Gua-gua Prasejarah Pangkep-Maros-Sulawesi Selatan. Jakarta: Penerbit Wedatama Widya Sastra.

Raphaël, M. 1945. Prehistoric cave paintings. The Bollingen Series IV. New York: Princeton University Press. 1986. Trois Essais sur la Signification de l'art Pariétal Paléolithique. Paris: Le Couteau dans

la plaie/Kronos.

Richter, J., 1991. Studien zur Urgeschichte Namibias. Cologne: Heinrich-Barth-Institut.

Sauvet, Georges dan A. Wlodarczyk. 2000-2001. L'Art Pariétal, Miroir des sociétés paléolithiques. Zephyrus $53-54,215-38$.

Sauvet, Georges; Robert Layton; Tilman Lenssen-Erz; Paul Taçon; dan Andre Wlodarczyk. 2009. Thinking with Animals in Upper Palaeolithic Rock Art, Cambridge Archaeological Journal 19: 3, McDonald Institute for Archaeological Research.

Simanjuntak, Truman. 2008. Austronesian in Sulawesi: It's Origin, Diaspora, and Living Tradition. Dalam Austronesian in Sulawesi, diedit oleh Truman Simanjuntak, 125-143. Yogyakarta: Galangpress.

Smith, Phillip. 2001. Cultural Theory; an Introduction. New Jersey: Blackwell.

Storey, Alice A., et al. 2012. Investigating the Global Dispersal of Chickens in Prehistory Using Ancient Mitochondrial DNA Signatures. http://journals.plos.org/ (diakses 5 April 2016).

Taçon, Paul S.C. 1988. Identifying Fish Species in the Recent Rock Paintings of Western Arnhem Land. Rock Art Research 5, 3-15.

Taçon, Paul S.C. dan C. Chippindale. 2008. Changing places: ten thousand years of north Australian rock-art transformation. Dalam Time and Change: Archaeological and Anthropological Perspectives in the Long- 
Term in Hunter-Gatherer Societies, diedit oleh D. Papagianni, H. Maschner \& R. Layton, 73-94. Oxbow Press: Oxford.

Taylor, L. 1996. Seeing the Inside. Oxford: Oxford University Press.

Teit, J. 1918. Notes on Rock Paintings in General, 1918. Unpublished manuscript, Glenbow Alberta Institute Archives.

Walter, Chip dan Stephen Alvarez (Photographs). 2015. Fist Artists. Dalam National Geographic, The book of Firsts, January 2015, Vol. 227, No.1: 33-57.

Whitley, David S. 1994. By the Hunter, for the Gatherer: Art, Social Relations and Subsistence Change in the Prehistoric Great Basin. World Archaeology 25, 356-73. 2005. Introduction to Rock Art Research. California: Left Coast Press Inc.

Whitley, David S., Joseph M. Simon, dan Ronald I. Dorn.1998. Rock Art Studies at CA-SBR-2347, The Paradise Bird Site, Fort Irwin N.T.C; San Bernandino County, California: Report on film Archaeological Information Center, San Bernandino County Museum.

Harry Widianto. 2008. Human Arrival and Its Dispersal during The Holocene in Sulawesi. Dalam Austronesian in Sulawesi, diedit oleh Truman Simanjuntak, 23-32. Yogyakarta: Galangpress.

. 2010. Jejak Langkah setelah Sangiran. Balai Pelestarian Situs Manusia Purba Sangiran. Direktorat Peninggalan Purbakala, Direktorat Jenderal Sejarah dan Purbakala, Kementerian Kebudayaan dan Pariwisata.

York, A.; R. Daly; dan C. Arnett. 1993. They Write their Dreams on the Rock Forever. Rock Writings in the Stein River Valley of British Columbia. Vancouver: Talonbooks. 